\title{
Penggunaan Metode System Usability Scale Untuk Mengukur Aspek Usability Pada Media Pembelajaran Daring Di Universitas XYZ
}

\author{
Dorie P. Kesuma \\ Universitas Multi Data Palembang; Jl. Rajawali No.14, Telp: (0711) 379249 \\ Jurusan Sistem Informasi, Universitas Multi Data Palembang, Palembang \\ e-mail: dpkesuma@staff.mdp.ac.id
}

\begin{abstract}
Abstrak
Penelitian ini bertujuan untuk mengevaluasi media pembelajaran daring di Universitas XYZ pada aspek usability menggunakan metode System Usability Scale (SUS) dengan 10 pertanyaan sebagai tolak ukur kualitas dari aspek usability layanan LMS tersebut. Sebanyak 50 responden dari kalangan mahasiswa dilibatkan dalam penelitian ini. Hasil pengujian menunjukkan penilaian System Usability Scale (SUS) berada pada skor rata-rata 69,9. Dari hasil tersebut, maka layanan media pembelajaran daring Universitas XYZ mendapat grade $\mathrm{C}$, peringkat persentilnya berada pada kisaran $52 \%$, masuk dalam kategori OK untuk sifatnya (Adjective) dan masuk dalam kategori marginal untuk tingkat penerimaannya (Acceptable) dan untuk nilai NPS-nya sediri tergolong passive. Hasil yang diperoleh menempatkan media pembelajaran daring Universitas XYZ sebagai layanan yang masih bisa diterima oleh para mahasiswa, tetapi perbaikan masih tetap diperlukan untuk meningkatkan kepuasan mahasiswa sebagai pengguna layanan yang dapat berdampak pada peningkatan hasil belajar mahasiswa.
\end{abstract}

Kata kunci: LSM, SUS, usability

\begin{abstract}
This study aims to evaluate online learning media at XYZ University on the usability aspect using the System Usability Scale (SUS) method with 10 questions to measure the quality of the usability aspect of the LMS service. A total of 50 respondents from among students were involved in this study. The test results show the System Usability Scale (SUS) assessment is at an average score of 69.9. From these results, $X Y Z$ University's online learning media service received grade $C$, the percentile rating was in the range of 52\%, included in the OK category for its nature aspect (Adjective), and included in the marginal category for its acceptance rate (Acceptable) and for its NPS value, classified as passive. This results place XYZ University's online learning media as a service that acceptable by it's student. However, improvements are still needed to increase student satisfaction as service users, which can impact improving student learning outcomes.
\end{abstract}

Keyword: LMS, SUS, usability 


\section{PENDAHULUAN}

Keberadaan media pembelajaran yang dapat mengakomodir proses belajar mengajar antara mahasiswa dan dosen secara daring di lingkungan pendidikan tinggi terus mengalami perkembangan yang semakin signifikan dari waktu ke waktu. Salah satu faktor yang mempengaruhinya adalah perkembangan teknologi informasi yang terus meningkat yang mendorong berbagai institusi dan organisasi untuk menerapkan berbagai bentuk teknologi informasi yang ada dalam upaya untuk memperoleh suatu keuntungan kompetitif di era sekarang khususnya di bidang pendidikan tinggi.

Kebutuhan akan suatu bentuk media pembelajaran yang berbasiskan teknologi informasi yang dapat berjalan secara daring dapat memberikan suatu solusi bagi institusi pendidikan tinggi atas kekurangan-kekurangan yang terdapat pada model pembelajaran konvensional, seperti keharusan untuk melakukan pertemuan secara tatap muka atau harus adanya interaksi langsung antara mahasiswa dan dosen yang mana pola ini tidak akan berjalan jika mahasiswa atau dosen tidak hadir pada kegiatan belajar mengajar. Hal inilah yang kemudian mendorong Universitas XYZ sebagai salah satu penyelenggara pendidikan tinggi swasta di kota Palembang untuk mengembangkan suatu media pembelajaran daring yang dapat dimanfaatkan oleh setiap mahasiswa dan dosen-dosennya dalam melaksanakan kegiatan belajar mengajar.

Universitas XYZ yang penyelenggaraan pendidikannya berfokus pada ilmu komputer telah lama menyadari pentingnya pemanfaatan teknologi informasi di bidang pendidikan yaitu untuk memperbaiki posisi kompetitif organisasi, meningkatkan brand image organisasi, meningkatkan kualitas pembelajaran dan pengajaran, meningkatkan kepuasan mahasiswa, meningkatkan pendapatan organisasi, memperluas basis mahasiswa, meningkatkan kualitas pelayanan, mengurangi biaya operasi, dan mengembangkan produk dan layanan baru [1].

Dikarenakan media pembelajaran daring yang dikembangkan ini digunakan oleh banyak pihak untuk berbagai keperluan di lingkungan Universitas XYZ secara terus menerus, maka aspek yang harus menjadi perhatian dari pihak ICT Universitas XYZ antara lain adalah memastikan penerapan LMS yang mampu melibatkan semua penggunanya dan memiliki kemampuan user interface dan user experience yang sangat baik untuk benar-benar dapat melibatkan pengguna dan membuat sistem pembelajaran yang benar-benar efektif [2]. Aspek lainnya yang perlu menjadi perhatian adalah faktor kegunaan atau aspek usability dari media pembelajaran daring tersebut. Faktor kegunaan atau usability adalah sampai sejauh mana suatu produk dapat digunakan oleh penggunanya untuk mencapai target yang telah ditetapkan dengan efektif dan efisien dan mencapai kepuasan pengguna dalam konteks tertentu [3]. Faktor kegunaan atau usability ini juga dapat didefinisikan sebagai atribut kualitas yang menjelaskan atau mengukur seberapa mudah penggunaan suatu antar muka (user interface). Kata usability ini juga merujuk pada suatu metode untuk meningkatkan kemudahan pemakaian selama proses desain. Usability dapat diukur dengan lima kriteria, yaitu learnability, efficiency, memorability, errors, dan satisfaction [4].

Menurut pedoman tentang usability, suatu layanan web, termasuk media pembelajaran daring harus bisa memenuhi harapan penggunanya atas komponen navigasi, konten, dan organisasi web yang bersangkutan [5] sehingga perlu dinilai atau dievaluasi hasil kerja dari layanan web tersebut untuk melihat sejauh mana keberhasilannya dalam mencapai tujuan dan sasaran awal yang telah ditetapkan [6]. Lebih lanjut, paling tidak ada lima alasan yang dapat menggambarkan pentingnya proses evaluasi faktor usability pada suatu layanan web tertentu, yaitu untuk mengetahui apakah layanan yang disediakan telah memenui harapan pengguna, mencocokkan antara keputusan bisnis dengan penggunaan di dunia nyata, menghilangkan cacat pada layanan, memungkinkan penyedia layanan untuk melihat seberapa besar keberhasilan 
pengguna dalam menyelesaikan keperluannya dan berguna untuk memperoleh reaksi dari pengguna serta masukan mereka terkait dengan layanan yang disediakan [7]. Secara umum faktor kegunaan atau usability ini penting karena bagi suatu layanan berbasis web, usability menjadi suatu tolak ukur yang diperlukan untuk bisa bertahan dari para pesaingnya [4].

Penelitian ini dilakukan untuk mengukur tingkat usability pada layanan media pembelajaran daring yang disediakan oleh pihak Universitas XYZ dari sisi mahasiswa sebagai salah satu pengguna aktif layanan tersebut dengan menggunakan metode SUS atau System Usability Scale yang diperkenalkan oleh J Brooke pada tahun 1986 [8]. Metode SUS bersifat quick and dirty dan berbasiskan pada kuesioner yang terdiri dari sepuluh pertanyaan tanpa membutuhkan banyak sampel sebagai sumber datanya sehingga metode SUS ini tergolong metode yang efektif, murah dan paling umum digunakan [9] [8]. Pada perkembangannya, penelitian sebelumnya [10] mendapati bahwa metode SUS versi Indonesia masuk dalam kategori reliabel sehingga metode SUS ini dapat digunakan oleh pakar usability multi bidang untuk mengevaluasi tingkat usability produk atau digunakan untuk kepentingan riset.

\section{METODE PENELITIAN}

\subsection{Langkah-langkah Penelitian}

Penelitian ini dilakukan dengan menggunakan serangkaian proses yang tergambarkan di dalam diagram langkah penelitian seperti yang dapat dilihat pada Gambar 1 dibawah.

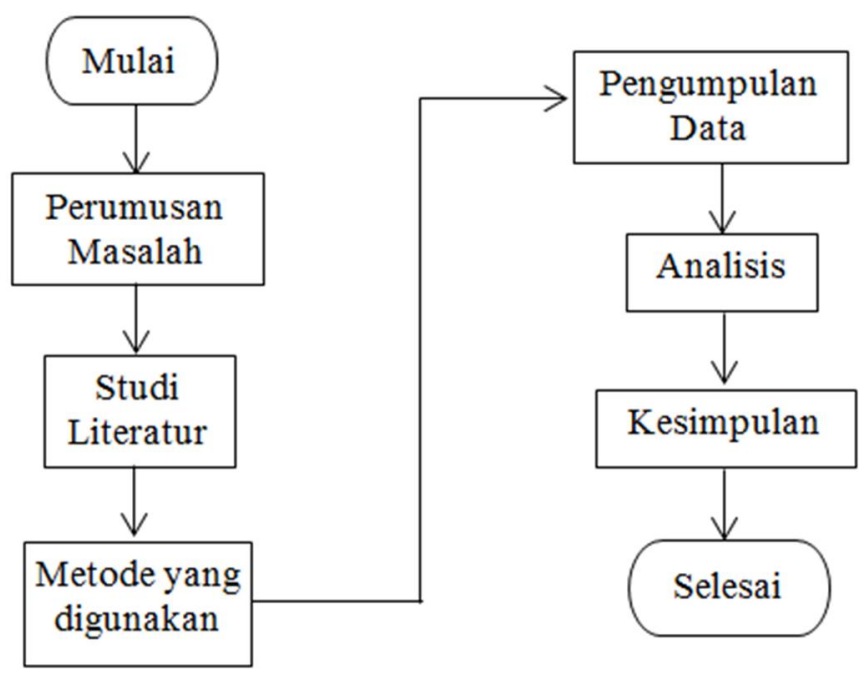

Gambar 1. Langkah Penelitian

\subsection{Perumusan Masalah}

Pada tahap perumusan masalah telah ditetapkan bahwa yang menjadi subjek di dalam penelitian ini adalah layanan media pembelajaran daring yang tersedia di Universitas XYZ dengan penggunanya dari kalangan mahasiswa yang berjumlah 88 orang. Jumlah ini tidak menjadi masalah untuk digunakan pada metode SUS dikarenakan metode ini memang tetap bisa digunakan meskipun dengan jumlah sampel yang sedikit [9]. Ada pun yang menjadi objek penelitian ini adalah faktor kegunaan atau usability dari media pembelajaran daring di Universitas XYZ untuk dilihat sampai sejauh mana aspek usability pada layanan ini dapat memenuhi harapan penggunanya. 


\subsection{Studi Literatur}

Beberapa konsep yang menjadi dasar dari penelitian ini telah dijelaskan sebelumnya pada Bab 1 Pendahuluan. Pada bagian ini, penulis menambahkan beberapa konsep lagi dari hasil studi literatur yang telah dilakukan untuk menambah kejelasan akan topik yang dijadikan dasar dari penelitian ini.

\subsubsection{LMS}

LMS dapat diartikan sebagai suatu platform perangkat lunak berbasis web yang menyediakan sebuah lingkungan pembelajaran interaktif secara daring dan dapat mengotomatisasi tugas administratif dan organisasi, menyampaikan dan melaporkan baik konten pendidikan dan juga hasil dari para pesertanya [11]. Sebuah LMS juga berisi fitur-fitur elektronik seperti media diskusi, file, buku nilai, e-mail, pengumuman, penilaian, dan elemen multimedia lainnya [12] dan dapat membantu mahasiswa untuk mengakses informasi pembelajaran melalui pedoman akademik, mengunggah tugas dan mengunduh nilai, berinteraksi secara aktif antara mahasiswa dengan dosen, antar sesama mahasiswa, dan dengan perangkat pembelajaran, dapat berbagi ilmu, serta mengikuti ujian dan kuis secara daring [13].

\subsubsection{Usability}

Berbicara mengenai aspek usability pada suatu produk atau layanan, maka ada beberapa atribut kualitas didalam produk atau layanan tersebut yang harus terpenuhi dan terjaga. ISO 9241 menyebutkan jika ukuran usability harus mencakup tiga atribut kualitas sebagai berikut [3]:

1. Efektivitas

Efektivitas menunjukkan tingkat akurasi dan kesempurnaan yang dicapai pengguna saat menjalankan tugas tertentu.

2. Efisiensi

Efisiensi menunjukkan sumber daya yang digunakan terkait dengan akurasi dan kesempurnaan yang dicapai pengguna dalam menjalankan tugas.

3. Kepuasan

Kepuasan menunjukkan kondisi pengguna yang terbebas dari rasa tidak nyaman dan menunjukkan perilaku positif terhadap penggunaan sistem.

Jika menurutt Nielsen maka ada lima atribut kualitas pada aspek usability, yaitu [4]:

1. Learnabilty

Menjelaskan seberapa mudah pengguna website dalam mempelajari dan menyelesaikan tugas-tugas mendasar ketika baru pertama kali mengunjungi suatu website.

2. Efficiency

Menjelaskasn tingkat kecepatan pengguna dalam menyelesaikan tugas-tugas lain setelah mempelajari isi dari suatu website.

3. Memorability

Menjelaskan tingkat pemahaman pengguna terhadap website setelah pengguna tersebut tidak lagi menggunakan website tersebut dalam jangka waktu yang lama.

4. Error

Menunjukkan seberapa banyak tingkat kesalahan yang dilakukan oleh pengguna website, seberapa berat kesalahan yang dilakukannya dan seberapa mudah pengguna website mengatasi kesalahan yang terjadi ketika sedang menggunakan website tersebut.

5. Satisfaction

Menjelaskan tingkat kepuasan pengguna dalam menggunakan website tersebut. 


\subsection{Metode Analisis}

Metode analisis data yang digunakan pada penelitian ini adalah metode System Usability Scale (SUS). Untuk penjelasan singkat mengenai metode ini, telah dijelaskan di Bab 1 Pendahuluan di atas.

\subsubsection{Metode SUS}

System Usability Scale merupakan metode yang cepat untuk dikelola dan murah untuk digunakan, terlebih jika dilakukan secara online. Metode SUS merupakan salah satu cara yang paling efisien untuk mengumpulkan data yang valid secara statistik dan memberikan hasil skor yang jelas dan cukup tepat. Meskipun begitu, metode SUS masih cukup valid untuk digunakan [14].

Ada beberapa alasan kenapa metode SUS ini baik untuk digunakan dalam mengukur aspek usability suatu produk atau layanan, yaitu [8] [15]:

1. SUS dapat digunakan dengan mudah, karena hasilnya berupa angka skor 0 - 100 dan sudah tersedia template yang tinggal digunakan untuk melakukan proses perhitungannya.

2. SUS sangat mudah digunakan, tidak membutuhkan perhitungan yang rumit mudah dan tidak memerlukan banyak sumber daya untuk mengelolanya.

3. SUS tersedia secara gratis, tidak membutuhkan biaya tambahan.

4. SUS terbukti valid dan reliable, walau dengan ukuran sampel yang kecil.

5. SUS dapat membantu penyedia produk atau layanan dalam mengevaluasi apakah suatu sistem perlu diperbarui.

6. SUS dapat membantu mengevaluasi efektivitas perbaikan sistem dari waktu ke waktu.

7. SUS dapat memberikan keyakinan kepada pemilik bisnis untuk berinvestasi lebih jauh di bidang user experience dari produk atau layanan yang dimilikinya.

Meskipun begitu, ada hal-hal tertentu yang harus diperhatikan ketika menggunakan metode ini, yaitu [16] [17]:

1. Sistem penilaiannya agak rumit.

2. Karena hasil skornya berupa angka pada skala 0-100, maka kebanyakan orang akan menafsirkannya dalam bentuk persentase, padahal tidak seperti itu.

3. Cara terbaik untuk menafsirkan hasil skor yang diperoleh adalah dengan menormalkan hasil skor tersebut untuk menghasilkan peringkat persentil yang diinginkan.

4. Metode ini tidak bersifat diagnostik, atau dengan kata lain metode SUS tidak dimaksudkan untuk mendiagnosa masalah pada aspek usability suatu produk atau layanan.

\subsubsection{Kuesioner SUS}

Metode SUS bekerja berdasarkan data yang diperoleh dari penyebaran kuesioner kepada responden yang menggunakan skala likert yang mencakup 10 pertanyaan yang akan dijawab oleh pengguna produk atau layanan. Para responde akan memberi penilaian untuk setiap pertanyaan berdasarkan skala 1 sampai 5 berdasarkan seberapa setuju mereka dengan pernyataan yang ada di dalam kuesioner SUS. Skala 5 berarti sangat setuju, sedangkan skala 1 berarti sangat tidak setuju. Tabel 1 berikut ini berisikan daftar 10 pertanyaan yang terdapat pada kuesioner SUS [10].

Tabel 1. Daftar Pertanyaan Kuesioner SUS

\begin{tabular}{|l|l|}
\hline No & \multicolumn{1}{c|}{ Pertanyaan } \\
\hline 1 & Saya berpikir akan menggunakan sistem ini lagi \\
\hline 2 & Saya merasa sistem ini rumit untuk digunakan \\
\hline 3 & Saya merasa sistem ini mudah digunakan \\
\hline
\end{tabular}




\begin{tabular}{|l|l|}
\hline 4 & Saya membutuhkan bantuan dari orang lain atau teknisi dalam menggunakan sistem ini \\
\hline 5 & Saya merasa fitur-fitur sistem ini berjalan dengan semestinya \\
\hline 6 & Saya merasa ada banyak hal yang tidak konsisten (tidak serasi pada sistem ini) \\
\hline 7 & Saya merasa orang lain akan memahami cara menggunakan sistem ini dengan cepat \\
\hline 8 & Saya merasa sistem ini membingungkan \\
\hline 9 & Saya merasa tidak ada hambatan dalam menggunakan sistem ini \\
\hline 10 & Saya perlu membiasakan diri terlebih dahulu sebelum menggunakan sistem ini \\
\hline
\end{tabular}

\subsubsection{Menghitung Skor SUS}

Setelah kuesioner SUS disebarkan dan para responden yang telah dipilih telah memberikan penilaian mereka terhadap kesepuluh pertanyaan di dalam kuesioner tersebut, maka langkah selanjutnya adalah melakukan proses perhitungan untuk data-data tersebut. Disini ada beberapa aturan dalam melakukan perhitungan skor SUS.

1. Untuk setiap pertanyaan bernomor ganjil, hasil skornya dikurangi angka 1.

[Penilaian pengguna $-1=$ skor pertanyaan]

Untuk setiap pertanyaan bernomor genap, maka kita harus mengurangi angka 5 dengan hasil skornya.

[5 - Penilaian pengguna $=$ skor pertanyaan $]$

2. Kemudian jumlahkan semua hasil skor dari setiap pertanyaan per responden, kemudian hasilnya dikalikan dengan angka 2,5.

$[[$ Skor pertanyaan ke 1$]+[$ Skor pertanyaan ke 2] $+\ldots+[$ Skor pertanyaan ke $n] * 2.5=$ skor responden]

3. Jumlahkan semua hasil skor setiap responden yang telah melalui langkah 1 hingga 3 diatas, kemudian hitung nilai rata-ratanya.

[Total skor responden] / jumlah responden $=$ Hasil Skor SUS

\subsubsection{Menginterpretasikan Skor SUS}

Dalam menginterpretasikan hasil skor SUS, ada lima cara yang bisa digunakan yaitu dengan berdasarkan pada interpretasi perbandingan peringkat persentil, peringkat, sifat, tingkat penerimaan, dan NPS dari skor SUS itu sendiri [18] dan dapat dilihat dalam bentuk gambar skala interpretasi pada Gambar 3 berikut ini.

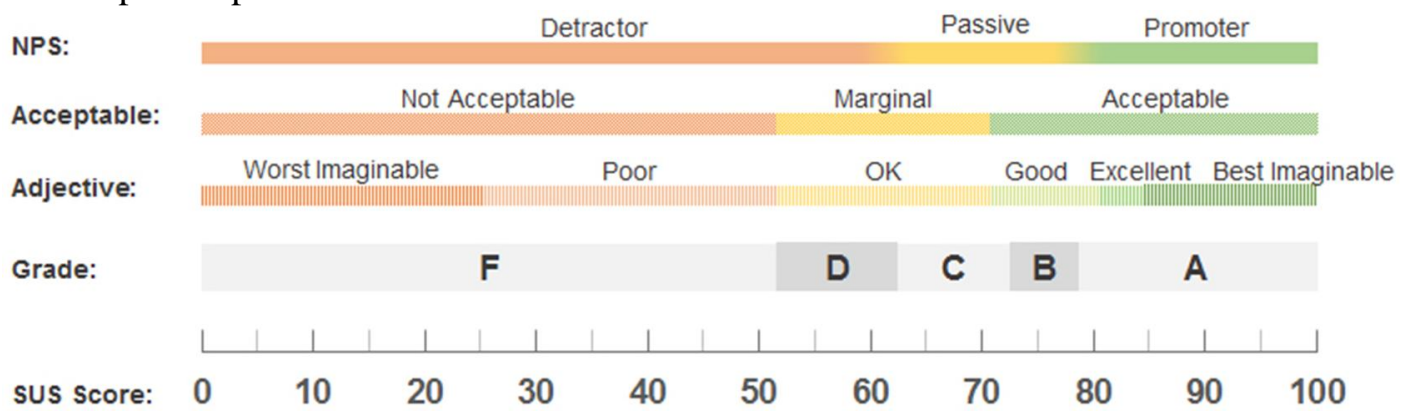

Gambar 3. Skala Interpretasi Hasil Skor SUS

Tabel 5 berikut memberikan gambaran yang lebih jelas mengenai nilai-nilai yang terdapat pada Gambar 3 diatas. 
Tabel 5. Skala Interpretasi Hasil Skor SUS

\begin{tabular}{|c|c|c|c|c|c|}
\hline Grade & SUS & Percentile range & Adjective & Acceptable & NPS \\
\hline $\mathrm{A}+$ & $84.1-100$ & $96-100$ & Best Imaginable & Acceptable & Promoter \\
\hline $\mathrm{A}$ & $80.8-84.0$ & $90-95$ & Excellent & Acceptable & Promoter \\
\hline A- & $78.9-80.7$ & $85-89$ & \multirow{5}{*}{ Good } & Acceptable & Promoter \\
\hline $\mathrm{B}+$ & $77.2-78.8$ & $80-84$ & & Acceptable & Passive \\
\hline B & $74.1-77.1$ & $70-79$ & & Acceptable & Passive \\
\hline B- & $72.6-74.0$ & $65-69$ & & Acceptable & Passive \\
\hline $\mathrm{C}+$ & $71.1-72.5$ & $60-64$ & & Acceptable & Passive \\
\hline $\mathrm{C}$ & $65.0-71.0$ & $41-59$ & \multirow{3}{*}{$O K$} & Marginal & Passive \\
\hline $\mathrm{C}-$ & $62.7-64.9$ & $35-40$ & & Marginal & Passive \\
\hline $\mathrm{D}$ & $51.7-62.6$ & $15-34$ & & Marginal & Detractor \\
\hline
\end{tabular}

Dari Gambar 3 diatas, bisa dilihat jika interpretasi hasil skor SUS dapat dilakukan dengan menggunakan lima pendekatan yang berbeda-beda. Berikut penjelasan untuk masing-masing pendekatan tersebut [19].

1. Peringkat Persentil (Percentiles Rank)

Untuk mengkonversi hasil skor SUS ke dalam peringkat persentil, maka digunakan alat bantu berupa grafik kurva seperti yang ditampilkan pada Gambar 4 berikut ini. Grafik kurva ini dikembangkan oleh J Sauro yang telah mengobservasi lebih dari 5000 objek SUS [20] dengan menggunakan skala dari Bangor seperti pada Gambar 3 diatas.

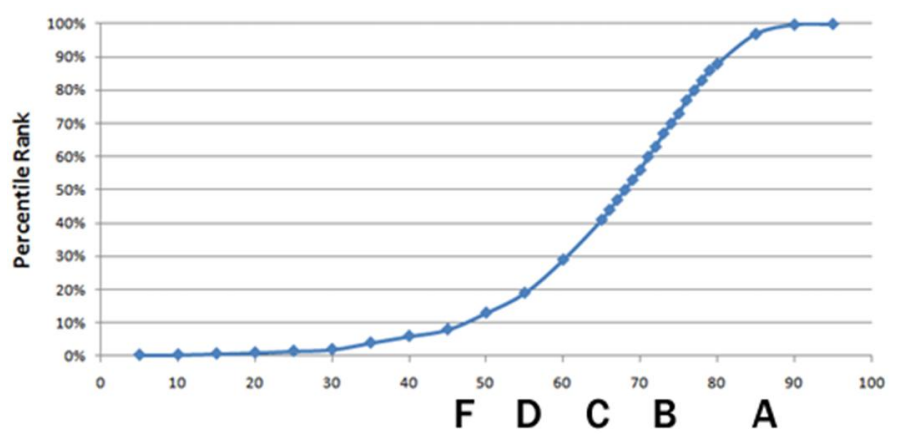

Gambar 4. Grafik Kurva Sauro

Contoh penggunaan grafik kurva Sauro tersebut dapat dilihat pada Gambar 5 berikut ini dimana untuk hasil skor SUS sebesar 68 (grade C), maka peringkat persentilnya ada di peringkat ke 50\%, yang mana merupakan nilai standar untuk interpretasi nilai SUS.

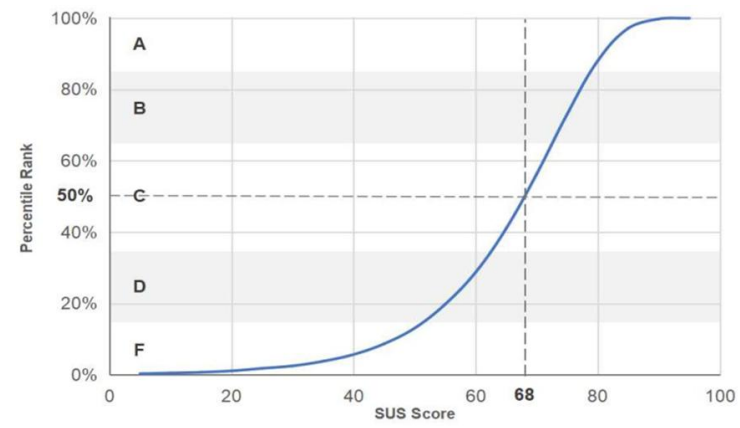

Gambar 5. Contoh Nilai Persentil Hasil Skor SUS 
2. Peringkat (Grades)

Untuk peringkat, nilai mentah skor SUS dapat dikelompokkan ke dalam peringkat-peringkat mulai dari peringkat $A$ hingga $F$, dimana peringkat $A$ berarti sangat baik, dan peringkat $F$ berarti sangat buruk.

3. Sifat (Adjectives)

Nilai mentah skor SUS juga dapat disandingkan dengan salah satu dari enam sifat yang ada. Skor SUS yang berada di atas nilai 85 dikatakan Sempurna / Exellent, nilai 72 keatas masuk dalam kategori Baik / Good, atau nilai 51 untuk OK.

4. Tingkat Penerimaan (Acceptible)

Variasi lain dalam menginterpretasikan nilai skor SUS ini adalah dengan melihat tingkat penerimaan nilai mentah skor SUS. Tingkat penerimaan "Dapat Diterima" untuk nilai skor di atas 70 dan untuk "Tidak Dapat Diterima" mulai dari nilai skor 50 ke bawah. Nilai skor antara 50 - 70 dianggap "Dapat Diterima Secara Marginal", yang mencakup rentang dari C hingga $\mathrm{D}$ dalam skala peringkat.

5. Net Promotore Score (NPS)

Yang terakhir adalah NPS. NPS merupakan survei tingkat kepuasan dan keloyalan pengguna terhadap sebuah produk yang berkaitan dengan seberapa besar kemungkinan pengguna merekomendasikan produk tersebut kepada orang lain. NPS menetapkan tiga kelas pemberi rekomendasi berdasarkan tanggapan mereka terhadap kemungkinan 11 poin (0 sampai 10) untuk merekomendasikan pertanyaan. Kelas promoter untuk skor 9 dan 10, kelas passive untuk skor 7 dan 8, dan kelas detractors untuk skor 6 kebawah.

\subsection{Pengumpulan Data}

Metode pengumpulan data yang digunakan di dalam penelitian ini adalah dengan menggunakan kuesioner yang terdiri dari 10 pertanyaan dengan menggunakan skala likert. Kuesioner yang digunakan di dalam penelitian ini menyadur dari hasil penelitian sebelumnya [10] yang disebarkan kepada tiga puluh responden pengguna website perguruan tinggi XYZ. Sedangkan dalam penelitian ini, jumlah responden yang ada berjumlah 50 responden yang merupakan mahasiswa di Universitas XYZ dari fakultas ilmu komputer.

\section{HASIL DAN PEMBAHASAN}

Setelah kuesioner disebar dan dikembalikan oleh para responden, maka selanjutnya dilakukan proses perhitungan untuk setiap data kuesioner dari masing-masing responden. Hasil rekapitulasi perhitungan tersebut dapat dilihat Tabel 6 berikut ini.

Tabel 6. Hasil Proses Perhitungan Skor SUS Media Pembelajarn Daring Universitas XYZ

\begin{tabular}{|l|l|l|l|l|l|}
\hline \multirow{2}{*}{ Responden } & \multicolumn{2}{|l|}{ Skor Hasil Hitung } & \multirow{2}{*}{ Responden } & \multicolumn{2}{|c|}{ Skor Hasil Hitung } \\
\cline { 2 - 3 } & Jumlah & Nilai & & Jumlah & Nilai \\
\hline R1 & 31 & 77,5 & R26 & 28 & 70 \\
\hline R2 & 29 & 72,5 & R27 & 31 & 77,5 \\
\hline R3 & 28 & 70 & R28 & 36 & 90 \\
\hline R4 & 40 & 100 & R29 & 30 & 75 \\
\hline R5 & 40 & 100 & R30 & 26 & 65 \\
\hline
\end{tabular}




\begin{tabular}{|c|c|c|c|c|c|}
\hline R6 & 29 & 72,5 & R31 & 35 & 87,5 \\
\hline R7 & 24 & 60 & R32 & 29 & 72,5 \\
\hline R8 & 20 & 50 & R33 & 30 & 75 \\
\hline R9 & 32 & 80 & R34 & 23 & 57,5 \\
\hline R10 & 29 & 72,5 & R35 & 22 & 55 \\
\hline R11 & 20 & 50 & R36 & 29 & 72,5 \\
\hline R12 & 28 & 70 & R37 & 37 & 92,5 \\
\hline R13 & 30 & 75 & R38 & 34 & 85 \\
\hline R14 & 28 & 70 & R39 & 32 & 80 \\
\hline R15 & 40 & 100 & $\mathrm{R} 40$ & 32 & 80 \\
\hline R16 & 31 & 77,5 & R41 & 25 & 62,5 \\
\hline R17 & 35 & 87,5 & $\mathrm{R} 42$ & 24 & 60 \\
\hline R18 & 20 & 50 & $\mathrm{R} 43$ & 36 & 90 \\
\hline R19 & 31 & 77,5 & $\mathrm{R} 44$ & 34 & 85 \\
\hline R20 & 27 & 67,5 & $\mathrm{R} 45$ & 21 & 52,5 \\
\hline R21 & 26 & 65 & R46 & 24 & 60 \\
\hline R22 & 27 & 67,5 & $\mathrm{R} 47$ & 31 & 77,5 \\
\hline R23 & 24 & 60 & $\mathrm{R} 48$ & 26 & 65 \\
\hline R24 & 28 & 70 & R49 & 23 & 57,5 \\
\hline R25 & 31 & 77,5 & R50 & 31 & 77,5 \\
\hline \multicolumn{6}{|c|}{ Skor Rata-Rata } \\
\hline \multicolumn{6}{|c|}{69,9} \\
\hline
\end{tabular}

Berdasarkan hasil rekapitulasi diatas, maka diperoleh angka 69,9 untuk nilai rata-rata pada skor SUS media pembelajaran daring Universitas XYZ. Dari sini sudah bisa dilakukan interpretasi data terhadap nilai rata-rata tersebut dengan menggunakan skala interpretasi hasil skor SUS dari Bangor seperti yang bisa dilihat pada Gambar 8 berikut ini.

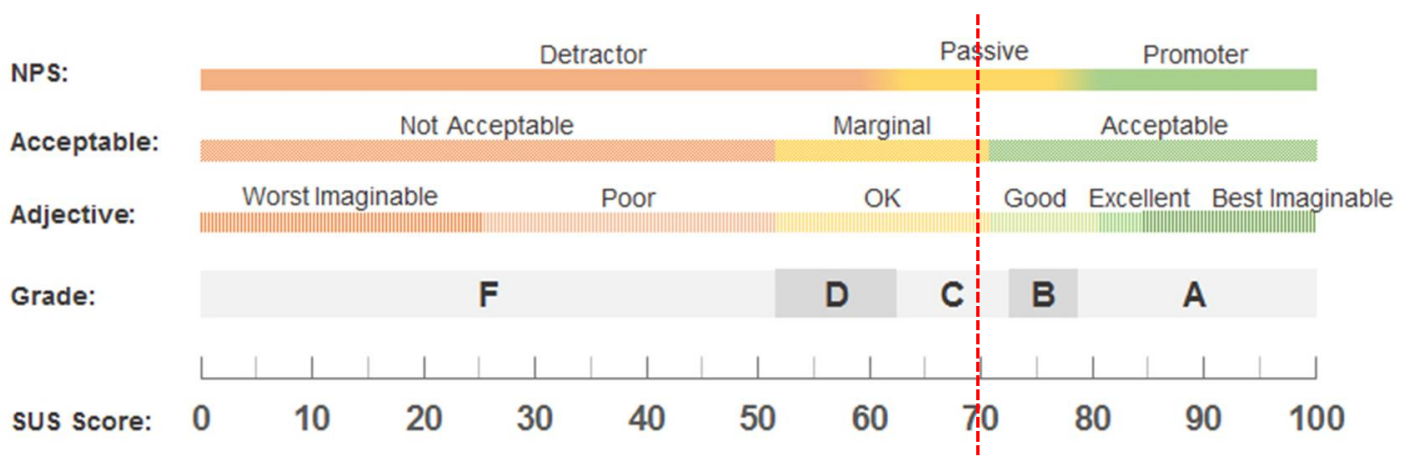

Gambar 8. Hasil Interpretasi Skor SUS Media Pembelajaran Daring Universitas XYZ

Dengan menggunakan garfik kurva Sauro pada Gambar 9 di bawah, diperoleh peringkat persentil untuk hasil SUS media pembelajaran daring Universitas XYZ berada pada peringkat $52 \%$. 


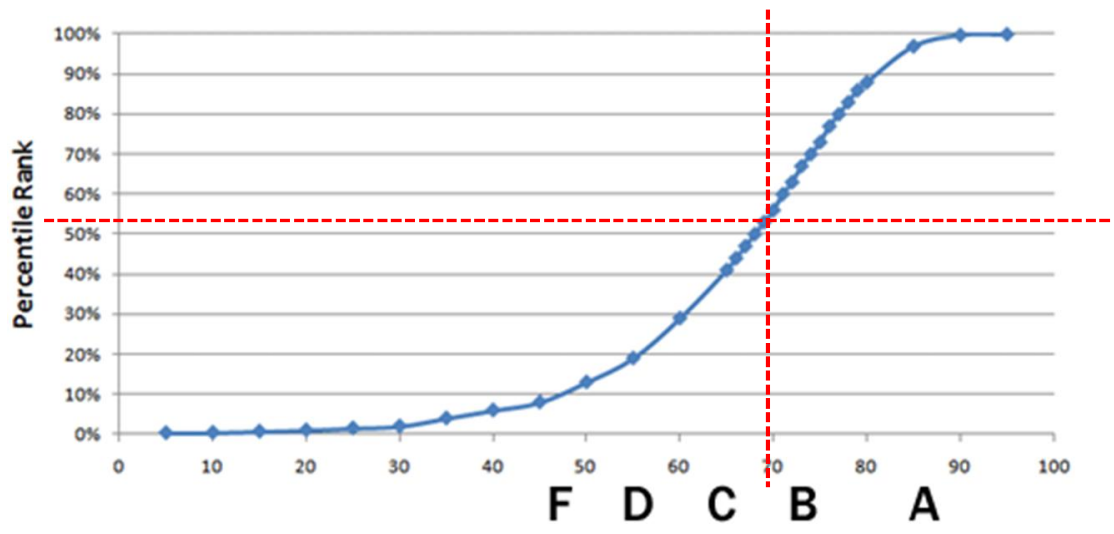

Gambar 9. Nilai Persentil Hasil Skor SUS Media Pembelajarn Daring Universitas XYZ

Hasil interpretasi yang lebih lengkap dapat dilihat pada Tabel 7 berikut ini dimana diketahui jika media pemebelajaran daring milik Universitas XYZ jika dilihat dari aspek usability-nya maka layanan tersebut mendapat grade C karena skor SUS-nya sebesar 69,9 dengan peringkat persentil berada pada kisaran 52\% yang masih sedikit berada di atas rata-rata, karena hasilnya yang hanya berbeda sedikit dengan standar skor SUS, yaitu sebesar 68. Untuk hasil interpretasi dari pendekatan berdasarkan sifat (Adjective), layanan milik Universitas XYZ ini masih termasuk kategori OK, dan tingkat penerimaannya (Acceptable) masuk kategori marginal yang berarti layanan ini masih bisa diterima secara umum oleh mahasiswa. Namun perlu diperhatikan bahwa untuk pendekatan interpretasi berdasarkan NPS, maka hasilnya adalah passive, dalam artian bahwa pengguna dari media pembelajaran daring Universitas XYZ ini tidak dalam kondisi menolak atau tidak mau menggunakan layanan ini, tetapi mereka juga tidak dalam kondisi sangat menyukai media pembelajaran daring tersebut. Persepsi para mahasiswa yang menjadi responden pada penelitian ini berada di tingkat menengah.

Tabel 7. Hasil Interpretasi Skor SUS Media Pembelajarn Daring Universitas XYZ

\begin{tabular}{|c|c|c|c|l|c|}
\hline Grade & SUS & Percentile range & Adjective & Acceptable & NPS \\
\hline C & $65.0-71.0$ & $41-59$ & OK & Marginal & Passive \\
\hline
\end{tabular}

\section{KESIMPULAN}

Proses pengolahan data SUS dan interpretasi atas hasil yang diperoleh oleh layanan media pembelajaran daring di Universitas XYZ bisa dilihat pada Bab 3 diatas. Hasil tersebut sudah bisa digunakan untuk membuat kesimpulan atas performa dari layanan yang disediakan oleh Universitas XYZ khususnya untuk para mahasiswanya begitu juga dengan kualitas dari aspek usability layanan tersebut juga sudah bisa diukur.

Dikarenakan media pembelajaran daring milik Universitas XYZ ini merupakan layanan internal dan menjadi satu-satunya LMS yang dapat digunakan oleh para mahasiswa dan dosen, maka gambaran yang dihasilkan di dalam penelitian ini masih bisa ditolerir oleh manajemen universitas dikarenakan sistem ini bukan sistem komersil sehingga tidak ada pesaingnya secara ekternal. Meskipun mahasiswa dan dosen bisa menggunakan media pembelajaran yang lain, 
seperti misanya melalui Google Classroom, tetapi keseluruhan proses pembelajaran daring di Universitas XYZ tetap harus dikembalikan ke LMS milik Universitas.

Tetapi jika dikaitkan dengan definisi dari aspek usability itu sendiri [3], maka hasil ini perlu menjadi perhatian dari pihak manajemen universitas. Jika dilihat dari aspek komersil tentunya tidak akan menjadi masalah, namun dikarenakan layanan ini digunakan sebagai media pembelajaran, maka kualitas dari layanan media pembelajaran daring ini harus menjadi perhatian tersediri karena menyangkut tingkat keberhasilan dan kepuasan mahasiswa dalam proses belajarnya.

\section{SARAN}

Berkaitan dengan hasil dari penelitian ini maka ada beberapa saran yang bisa menjadi perhatian dari pihak manajemen Universitas XYZ.

1. Dikarenakan kelemahan dari metode SUS, maka perlu dilakukan penelitian lanjutan yang dapat memberikan gambaran penyebab kenapa hasil dari perhitungan skor SUS untuk layanan media pembelajaran daring ini hanya mendapat angka 69,9.

2. Kedepannya bisa dilakukan penelitian dengan responden yang lebih bervariasi, misalnya dari angkatan yang berbeda-beda, dari jurusan yang berbeda, dan bisa juga dengan melihat latar belakang baik dari skill komputer yang dimiliki, waktu yang dihabiskan dalam menggunakan komputer atau internet, dan sebagainya yang dimiliki oleh para responden.

3. Membuat beberapa versi yang berbeda dari layanan LMS yang ada sekarang kemudian melakukan pengujian terhadap versi-versi LMS tersebut. Dengan menggabungkan aspekaspek bernilai positif dari berbagai versi LMS tersebut diharapkan kedepannya Universitas XYZ dapat memiliki layanan media pembelajaran daring yang lebih berkualitas yang dapat memenuhi harapan penggunanya.

\section{DAFTAR PUSTAKA}

[1] Maryam Alavi and R. Brent Gallupe, "Using Information Technology in Learning: Case Studies in Business and Management Education Programs," vol. 2, no. 2, 2003.

[2] Victoria Hoffman. (2017, Oct.) 6 Essential LMS Elements For Revolutionizing User Experience. [Online]. https://elearningindustry.com/revolutionizing-user-experience-6lms-elements

[3] ISO. (2018) Ergonomics of Human-System Interaction--Part 11: Usability. [Online]. https://www.iso.org/obp/ui/\#iso:std:iso:9241:-11:ed-2:v1:en

[4] Jakob Nielsen. (2012, Jan.) Usability 101: Introduction to Usability. [Online]. https://www.nngroup.com/articles/usability-101-introduction-to-usability/

[5] Ben Shneiderman. (2003) https://www.usability.gov/. [Online]. https://www.usability.gov/sites/default/files/documents/guidelines_book.pdf

[6] Falahah and Iwan Rijayana, "Evaluasi Implementasi Sistem Informasi Dengan Pendekatan Utility System (Studi Kasus Sistem ECampus Universitas Widyatama)," vol. 6, no. 2, 2011. 
[7] Quovantis. (2017, Nov.) UX Planet. [Online]. https://uxplanet.org/why-is-it-important-todo-usability-testing-5080a5640df3

[8] John Brooke, SUS: A Quick and Dirty Usability Scale (Usability Evaluation in Industry). London: Taylor and Francis, 1996.

[9] J. R. Lewis, "Usability Testing," 2006.

[10] Zahra Sharfina and Harry Budi Santoso, "An Indonesian adaptation of the System Usability Scale (SUS)," in 2016 International Conference on Advanced Computer Science and Information Systems, ICACSIS, Malang, 2016, pp. 145-146.

[11] Darren Turnbull, Ritesh Chugh, and Jo Luck, "Learning Management System: An Overview," in Encyclopedia of Education and Information Technologies.: Springer Nature, 2019, pp. 1-7.

[12] Gautreau Cynthia, "Motivational Factors Affecting the Integration of a Learning Management System by Faculty," Journal of Educators Online, vol. 8, no. 1, pp. 1-21, Jan. 2011.

[13] Tache JURUBESCU , "Learning Content Management Systems," Informatica Economica, vol. 12, no. 4, pp. 91-94, 2008.

[14] Nathan Thomas. How To Use The System Usability Scale (SUS) To Evaluate The Usability Of Your Website. [Online]. https://usabilitygeek.com/how-to-use-the-systemusability-scale-sus-to-evaluate-the-usability-of-your-website/

[15] Katharine Betteridge. What Every UXC Client Should Know About SUS Scores. [Online]. https://www.bentley.edu/centers/user-experience-center/what-every-client-should-knowabout-sus-scores

[16] Usability.gov. System Usability Scale (SUS). [Online]. https://www.usability.gov/how-toand-tools/methods/system-usability-scale.html

[17] Jeff Sauro. (2011, Feb.) Measuring Usability with the System Usability Scale (SUS). [Online]. https://measuringu.com/sus/

[18] A. Bangor, P. Kortum, and J. Miller, "Determining What Individual SUS Scores," Journal of Usability Studies, vol. 4, no. 3, pp. 114-123, 2009.

[19] Jeff Sauro. (2018, Sep.) 5 Ways to Interpret a SUS Score. [Online]. https://measuringu.com/interpret-sus-score/

[20] J. Sauro, A Practical Guide to the System Usability Scale: Background, Benchmarks, \& Best Practices.: Measuring Usability LLC, 2011. 